\title{
Where does the long "journey" of the camels go?
}

\author{
Helena Bauer \\ MA Animal Law and Society (UAB) \\ Project Assistant, Animals' Angels e.V.
}

Received: September 2018

Accepted: October 2018

Recommended citation. BAUER H., Where does the long "journey" of the camels go?, dA. Derecho Animal (Forum of Animal Law Studies) 9/4 (2018) - https://doi.org/10.5565/rev/da.379

\begin{abstract}
Hardly any of us knows about the sad and appalling story of the camels in Egypt. Once being esteemed in the Bedouin culture as "the Bedouin's constant companion" the role of the camels in the Arab world has turned over the centuries. Nowadays they are mainly used for sports and leisure or as 'farm' animals bred and kept for milk and meat production. Egypt is one of the most important countries importing live camels. Every year hundreds of thousands of camels are imported as 'slaughter' animals particularly from Somalia and Sudan to provide the internal Egyptian market with camel meat. These transports by road, foot or sea are extremely long and exhausting for the camels, and some of them do not survive the exertions. At the markets they are faced with very rough and brutal handling methods. However, the alarming and wide-spread animal welfare problems generated from the unbearable transport and handling conditions which the camels must endure on transports, markets and in slaughterhouses in Egypt are not discussed up to the present day. Egypt is lacking any animal welfare legislation. Even though being member of the World Organisation of Animal Health (OIE), Egypt does not comply with the OIE standards on animal welfare in which also the camels are included. Therefore, it is high time to put an end to the extreme suffering of the camels and grant them the protection status they deserve.
\end{abstract}

Keywords: camels, welfare, health, transport, slaughtering.

Resumen - ¿Qué destino tiene el largo “viaje” de los camellos?

Casi ninguno de nosotros/as conoce la triste y espantosa historia de los camellos en Egipto. Una vez considerados por la cultura beduina como "el compañero constante de los beduinos", el papel de los camellos en el mundo árabe ha cambiado a lo largo de los siglos. Hoy en día se utilizan principalmente para deportes y ocio o como animales "de granja" criados y mantenidos para la producción de leche y carne. Egipto es uno de los principales países importadores de camellos vivos. Cada año, cientos de miles de camellos son importados como camellos de "matanza" especialmente desde Somalia y Sudán para abastecer con carne 
de camello el mercado interno de Egipto. Estos transportes por carretera, caminando o por mar son extremadamente largos y extenuantes para los camellos, y algunos de ellos no sobreviven a los esfuerzos. En los mercados se enfrentan a métodos duros y brutales de manejo. Sin embargo, los alarmantes y generalizados problemas de bienestar animal generados por las insoportables condiciones de transporte y manejo que los camellos deben soportar en transportes, mercados y mataderos en Egipto no se han discutido hasta el día de hoy. Egipto carece de legislación sobre bienestar animal. A pesar de ser miembro de la Organización Mundial de Sanidad Animal (OIE), Egipto no cumple con las normas de la OIE sobre bienestar animal en las que también se incluyen los camellos. Por lo tanto, es hora de poner fin al sufrimiento extremo de los camellos y otorgarles el estado de protección que merecen.

Palabras clave: camellos, bienestar, salud, transporte, sacrificio.

If you ask people of Western societies today what they know about Egypt, most of them would probably talk about the Pyramids, the Nile and holidays. Maybe some of them would also be worried about the current political situation and prefer their next holidays to be somewhere else. And perhaps some would think of camels. But then most likely in a romantic-glorified picture of discovering the pyramids and the mystic ancient Egyptian world on the back of a camel. But hardly any of us knows about the sad and appalling story of the camels in Egypt, whose lives pass off as anything but romantic.

The relationship between humans and camels ${ }^{1}$ began in Arabia approximately 4000 years ago with the domestication of their wild ancestors. Due to their extraordinary capacity to live in deserts and semiarid regions, the camels played a vital role for the nomadic people surviving in these inhospitable areas. They had been esteemed in the Bedouin culture not only as "the nomad's nourisher, his vehicle of transportation and his medium of exchange" 2 but also as "the Bedouin's constant companion"3 over a long period of time. With the emerging trade between Arabia and the Mediterranean, the camels "contributed substantially to the rise of Arab society and culture" 4 by being used for transporting goods (like incense or spices), for exploring unknown regions and for going to war with them. Also, Western colonialists took a liking to exploit the camels for their benefits ${ }^{5}$, even though they belittled them with attributes of stupidity and arrogance - prejudices that, unfortunately, exist up to the present day ${ }^{6}$, just as the use and exploitation of camels for human purposes continues to exist. For many centuries, camels have been commercially exploited. Today, they are mainly bred and kept for milk, meat and fibre production, as well as for transport and leisure ${ }^{7}$. Worldwide, the population of camels is estimated as over 28 million individuals ${ }^{8}$, with the great majority living in North-Eastern Africa and the Middle East ${ }^{9}$. The highest numbers of camels are found in Somalia and Sudan ${ }^{10}$. Compared to these two countries, Egypt's camel

\footnotetext{
${ }^{1}$ The camels are divided in two species: Camelus dromedarius, the one-humped dromedary camel, whose distribution is mainly in Africa and the Middle East, and Camelus bactrianus, the two-humped Bactrian camel, whose distribution is in Central Asia and Mongolia (e.g. see Irwin, R. (2010) Camel). In this essay, I will only talk about the dromedary camel, hereinafter as "camel".

${ }^{2}$ Hitti, P.K. (1970) History of the Arabs, p. 21

${ }^{3}$ Ibid.

${ }^{4}$ Köhler-Rollefson, I. (2014) Camel Karma, p. 7

${ }^{5}$ Irwin, R. (2010) Camel. pp. 163-172, 194-195

${ }^{6}$ On the contrary to these prejudices, the camels are gentle and very social beings, living peacefully and without hierarchic encounters in their community (see: Heidicke, G. (2011) Kamele sind anders).

${ }^{7}$ http://www.fao.org/dairy-production-products/production/dairy-animals/camels/en/, 22.02.2018

${ }^{8}$ Including dromedary and Bactrian camels

${ }^{9} \mathrm{http}$ ://www.fao.org/dairy-production-products/production/dairy-animals/camels/en/, 22.02.2018

${ }^{10}$ According to the Food and Agriculture Organization (FAO) estimated 7.3 Mio camels live in Somalia
} 
population seems very low, with only $66.000^{11}$ to 142.000 individuals estimated in $2016^{12}$. However, the country plays a crucial role in the story of the long journeys of the camels.

Egypt is one of the most important countries that imports live camels. Every year hundreds of thousands of camels are imported as 'slaughter' animals particularly from Somalia and Sudan to provide the internal Egyptian market with camel meat ${ }^{13}$. Many of the camels arrive by sea transport to harbours like Adabiya ${ }^{14}$, but most of them are transported by road to Egyptian markets from where they are resold to different slaughterhouses. The journey of the camels is extremely long and exhausting, and some of them do not survive the exertions ${ }^{15}$. The camels often have been transported for more than a week, before even reaching the Sudanese-Egyptian border. From that border they must continue their journey by walking on foot for two days, until they reach the Egyptian quarantine stables in Abu Simbel where they stay for veterinary medical checks for up to three days. Unfortunately, these examinations are mainly focused on blood checks in order to examine the camels' state of health rather than on animal welfare aspects, like their body condition, exhaustion, stress or mental states. After complying with the quarantine, the camels are loaded on to big trucks and further transported to the markets. The biggest market in the country is in Birqash, near Cairo. The transports across Egypt to Birqash can additionally take up to more than 30 hours. During this time the animals are neither provided with food nor water, and nor do they receive any rest break, while being confined without a break on board the trucks in extremely crowded conditions. They cannot move the whole time since their legs are shackled to keep them in a sitting position. Once they arrive at the market, they are unloaded - literally speaking - by being thrown, kicked and beaten out of the truck with wooden prods. Many camels fall over, especially when one of their forelegs is still tied up or, no loading ramp is used. Often, they also get stuck with their legs in-between the opening flap of the trucks. The same level of violence is perpetrated against the animals when the loading procedures are carried out: the camels are forced by being hit, pushed and dragged onboard small pick-up trucks. Frequently, beatings are directed at body parts that are particularly sensitive, like the head, joints or genitals, and many camels suffer from bleeding noses, whipped eyes and other injuries, not to mention the psychological distress and suffering of these animals in such a violent environment ${ }^{16}$. Every week, up to 6000 'slaughter' camels from Sudan and Somalia are sold at the camel market in Birqash, Egypt.

In Egypt, camel meat is considered to be "an important source of cheap protein"17 resulting in a very high demand for it, meaning that the slaughtering rate of camels is over $120 \%{ }^{18}$. That is to say that much more camels are slaughtered than kept in Egypt. Accordingly, within this country that is stricken by political instability and an unsecure economic situation, the import of live camels is a lucrative business for many people, indicating an increasing trend of numbers of camels imported. Hand in hand with this is a change of farming practices, "with a significant increase of intensive production (of camels)

and more than 4.8 Mio camels in Sudan. See: http://www.fao.org/faostat/en/\#data/QA, 22.02.2018

${ }^{11} \mathrm{http}$ //www.oie.int/wahis_2/public/wahid.php/Countryinformation/Animalpopulation, 23.02.2018

$12 \mathrm{http}: / /$ www.fao.org/faostat/en/\#data/QA, 22.02.2018

${ }^{13}$ Kadim, I.T. et al. (2013) Camel Meat and Meat Products, and Napp, S. et al. (2018) Understanding the legal trade of cattle and camels and the derived risk of Rift Valley Fever introduction into and transmission within Egypt, 23.02.2018

${ }^{14}$ Napp, S. et al. (2018) Understanding the legal trade of cattle and camels and the derived risk of Rift Valley Fever introduction into and transmission within Egypt, 23.02.2018

${ }^{15}$ The following information have been received from and confirmed by traders and local workers, as well as gained from observations at the market of Birqash, near Cairo, during our Animals' Angels investigation in February 2018.

${ }^{16}$ Additional information: http://www.animals-angels.com/projects/camel-transports.html, 23.02.2018

${ }^{17}$ Napp, S. et al. (2018) Understanding the legal trade of cattle and camels and the derived risk of Rift Valley Fever introduction into and transmission within Egypt, 23.02.2018

${ }^{18}$ Kadim, I.T. et al. (2013) Camel Meat and Meat Products, 23.02.2018 
in peri-urban areas" ${ }^{19}$. It is not only in Egypt that camels are seen as the future 'livestock' in (semi-)arid regions, and research on their productivity and potential in intensive food production systems is growing constantly ${ }^{20}$. But there is no discussion taking place about the alarming and wide-spread animal welfare problems generated by the unbearable transport and handling conditions which the camels must endure during transport, markets and in slaughterhouses.

From a legal point of view there is sadly not much to expect at the moment either. Even though, in 2014, Article 45 of the Constitution of The Arab Republic of Egypt adopted the provision that "the State shall (...) guarantee humane treatment of animals" 21 , not much has changed for the animals since then. Still today, Egypt is lacking any animal protection legislation. Also, the fact that Egypt is a member of the World Organisation for Animal Health (OIE) and has thus agreed to "endorse th(e) application (of the OIE standards on animal welfare) at national level" 22 , has not changed the reality of the animals for the better. These OIE animal welfare standards were introduced for the first time in 2005 into the international OIE Terrestrial Animal Health Code and, inter alia, set up in Chapter 7.3 the provisions on transport of animals by land ${ }^{23}$. In its preamble the camels are precisely included into the group of animals to whom the recommendations must be applied. Furthermore, it is clearly stated that "the amount of time animals spend on a journey should be kept to the minimum" 24 as well as "the welfare of the animals during their journey is the paramount consideration and is the joint responsibility of all people involved" 25 . But as reality shows, the OIE standards are severely ignored in Egypt, as they are by other countries, too. Neither are the "animal handlers (...) experienced and competent" as stated in Article 7.3.2., nor do they treat the animals as humanely as required by Article 7.3.3.1. Also, the transport companies and drivers do not comply with the OIE standards, for example when transporting camels on vehicles that are not designed for animal transport ${ }^{26}$. The unloading and loading procedures at the market greatly violate the provisions laid down particularly in Article 7.3.8. and 7.3.10. These examples only describe few non-compliances with the OIE animal welfare standards, and unfortunately many more can be found in the long journeys of camels across Egypt. For the camels, these non-compliances cause tremendous suffering, and a shift towards an understanding of animal protection is urgently needed in Egypt. Therefore, the OIE, but also the international community, has to take over responsibility and push for a decisive change in favour for the camels in Egypt and beyond, so that one day they will hopefully be seen again as companions who deserve respect and kindness.

\footnotetext{
${ }^{19}$ Napp, S. et al. (2018) Understanding the legal trade of cattle and camels and the derived risk of Rift Valley Fever introduction into and transmission within Egypt, 23.02.2018

${ }^{20}$ Faye, B. (2015) Role, distribution and perspective of camel breeding in the third millennium economies, 23.02.2018

${ }^{21} \mathrm{https}$ //www.globalanimallaw.org/database/national/egypt/, 23.02.2018

${ }^{22} \mathrm{http}: / / w w w . o i e . i n t / e n / a n i m a l-w e l f a r e / a n i m a l-w e l f a r e-a t-a-g l a n c e /, 23.02 .2018$

${ }^{23} \mathrm{http} / /$ www.oie.int/index.php?id=169\&L=0\&htmfile=chapitre_aw_land_transpt.htm, 23.02.2018

${ }^{24}$ See Article 7.3.1. of the OIE Terrestrial Animal Health Code, $\overline{2} 3.02 .2018$

${ }^{25}$ See Article 7.3.3. of the OIE Terrestrial Animal Health Code, 23.02.2018

${ }^{26}$ See Article 7.3.3.2 of the OIE Terrestrial Animal Health Code, 23.02.2018
} 


\section{REFERENCES:}

- AIDAROS, H. (2005) Global perspectives - the Middle East: Egypt. Scientific and Technical Review of the Office International des Epizooties (OIE), 24(2). Online available: http://web.oie.int/boutique/extrait/aidaros589596.pdf [last consultation: 23.02.2018]

- ALARY, V. \& FAYE, B. (2016) The camel chains in East Africa- Importance of gaps between the data and the apparent reality. Journal of Camelid Science 9. Online available: https://www.researchgate.net/publication/312188462_Alary_V_Faye_B_2016_The_cam el_chains_in_East_Africa-

Importance_of_gaps_between_the_data_and_the_apparent_reality_Journal_of_Camelid _Science_9_p_p_1-22 [last date of consultation: $\overline{2} 1 . \overline{02} .2018]$

- ANIMALS' ANGELS (2018) Investigation into live camel transport in Egypt. Personal observations and interviews at Birqash camel market. Unpublished information.

- FAYE, B. (2013) Classification, History and Distribution of the Camel. In: Kadim, I.T. et al. Camel Meat and Meat Products. CAB International, Oxfordshire, UK. Online available: https://www.cabi.org/cabebooks/ebook/20123381050 [last consultation: 23.02.2018]

- FAYE, B. (2013) Camel Meat in the World. In: Kadim, I.T. et al. Camel Meat and Meat Products. CAB International, Oxfordshire, UK. Online available: https://www.cabi.org/cabebooks/ebook/20123381050 [last consultation: 23.02.2018]

- FAYE, B. (2015) Role, distribution and perspective of camel breeding in the third millennium economies. Emirates Journal of Food and Agriculture, 27 (4). Online available: https://www.ejfa.me/index.php/journal/article/view/679 [last consultation: 23.02.2018]

- HEIDICKE, G. (2011) Kamele sind anders. VerlagsKG Wolf, 1st edition. Magdeburg, DE.

- HITTI, P.K. (1970) History of the Arabs. From the earliest times to the present. Macmillian Education LTD, $10^{\text {th }}$ edition. Hampshire, UK. Online available: https://archive.org/stream/HistoryOfTheArabs-

PhilipK.Hitti/History\%20of\%20The\%20Arabs\%20-

\%20Philip\%20K.\%20Hitti\#page/n43/mode/2up [last consultation: 23.02.2018]

- IRWIN, R. (2010) Camel. Animal Series. Reaktion Books LTD, $1^{\text {st }}$ edition. London, UK.

- KADIM, I.T., MAHGOUB, O., FAYE, B. \& FAROUK, M.M. (2013) Camel Meat and Meat Products. CAB International, Oxfordshire, UK. Online available: https://www.cabi.org/cabebooks/ebook/20123381050 [last consultation: 23.02.2018]

- KÖHLER-ROLLEFSON, I. (2014) Camel Karma. Twenty Years Among India's Camel Nomads. Tranquebar Press. Chennai, India.

- MASIGA, W.N. \& MUNYUA, S.J.M. (2005) Global perspectives on animal welfare: Africa. Scientific and Technical Review of the Office International des Epizooties (OIE), 24(2). Online available: http://web.oie.int/boutique/extrait/masiga579-587.pdf [last consultation: 23.02 .2018$]$

- NAPP, S., CHEVALIER, V., BUSQUETS, N., CALISTRI, P., CASAL, J., ATTIA, M. et al. (2018) Understanding the legal trade of cattle and camels and the derived risk of Rift 
Valley Fever introduction into and transmission within Egypt. PLoS Neglegted Tropical Diseases 12 (1): e0006143. Online available: https://doi.org/10.1371/journal.pntd.0006143

- ROBINSON, J. (2016) Camels. Salem Press Encyclopaedia Of Science [serial online]. Online available: http://eds.a.ebscohost.com/eds/detail/detail?vid=0\&sid=f98dee95-f48b47f9-bb96-

42a53211a5ad\%40sessionmgr4008\&bdata $=$ JnNpdGU9ZWRzLWxpdmU\%3d\#AN=8732 $1334 \& \mathrm{db}=$ ers [last consultation: 23.02 .2018 ]

- WORLD ORGANISATION OF ANIMAL HEALTH (OIE) (2017) Terrestrial Animal Health Code. Chapter 7.3. Transport of animals by land. Online available: http://www.oie.int/index.php?id=169\&L=0\&htmfile=chapitre_aw_land_transpt.htm [last date of consultation: 23.02 .2018$]$

\section{INTERNET SOURCES:}

[last date of consultation: 23.02.2018]

- http://www.animals-angels.com/projects/camel-transports.html

- http://www.fao.org/dairy-production-products/production/dairy-animals/camels/en/

- http://www.fao.org/faostat/en/\#data/QA

- https://www.globalanimallaw.org/database/national/egypt/

- http://www.oie.int/en/animal-welfare/animal-welfare-at-a-glance/ 